\title{
Survivability in Exile: The Study of Formal and Informal Education of Boti Women in Maintaining the Tradition in "Rumah Bulat"
}

\author{
${ }^{1}$ Mernon Yerlinda Carlista Mage, ${ }^{2}$ Susana Prapunoto, ${ }^{3}$ A. Ign.Kristijanto \\ mernonmage@gmail.com
}

Magister Science of Psychology Satya Wacana Christian University Salatiga, Indonesia

\begin{abstract}
This research is aimed to examine the roles of education in forming survivability in exile of women of the Boti tribe during giving birth until the puerperium in "rumah bulat" (a traditional round-shaped house). The participants of this research were both primigravida and multigravida mothers. Secondary data were collected from interviewing the midwives and traditional leaders of "inner" Boti tribe. Data collection methods were done by having indepth interview and observation, while qualitative method was also used. The results of this research showed a very traditional process of giving birth and the puerperium, also lacking of proper health facilities. It was caused by the inability of formal education in answering how Boti women could apply and live healthy life and environmental cleanliness toward their physical needs. In different circumstances, the role of informal education emphasized by family members and traditional leaders to maintain the local tradition in order to be safe and prosperous has made the Boti women take and face the reality in order to exercise the belief of the tribe in surviving in exile, although having dilemmatic psychological impacts such as anxiety, fear, boredom, loneliness, depression, even trauma. However, informal education was found to have more influence in creating survivability of Boti women in exile.
\end{abstract}

Keywords: survivability; formal and informal education; exile in rumah bulat

\section{Introduction}

Boti tribe is a traditional tribe in South Timor Tengah regency, East Nusa Tenggara. This tribe becomes a tribe that preserves the traditions of Timor culture. One of the traditions that has been well-maintained is the tradition of giving birth to the puerperium done by Boti women in a traditional house called ume kbubu or "rumahbulat" (a round-shaped traditional house). This phenomenon can be seen obviously and well-practiced within the Inner Boti tribe, which is included as the clan of Halaik, with their belief in UisNeno meaning the Almighty God, the creator of the universe, and UisPahwhich means god ruling the world[1].

Within the Inner Boti tribe, the treatments for the women giving birth to the puerperium are similar to those of other places in Timor. Mothers and their babies spend at least 40 days in the "rumahbulat" after giving birth to undergo some traditional treatments such as tatobi (putting wet warm napkin onto the forehead) and also se' $i$ which means putting burned charcoal under the bed in order to keep the mothers and the babies warm. Furthermore, mothers and their babies are not allowed to be visited by anyone except some relatives who are giving the treatments. It is important to keep the temperature inside the "rumahbulat" warm to prevent the mothers and their babies from getting cold, while putting the burned charcoal under the bed is also done for 40 days or during the stay in "rumah bulat" since it is believed that by doing this, it would prevent the mothers and their babies from serious illnesses[2]. 
Meanwhile, data released by Central Statistics Agency (BPS) in 2017 which had been taken from the sub-district of Kie stated that during the period of 2015-2017, local public health center was visited by patients suffering from acute respiratory illness (ISPA) with the numbers of visits that reached 2251 times followed by acute gastritis with the numbers of visits that reached 1624 times[3]. Gastritis is an illness caused by psychosomatic disorder, and from the data, it showed that the level of psychological pressure was quiet high. Other supporting data taken from Health Agency of East Nusa Tenggara (inKinasih[4]) stated that acute respiratory illness contributed the highest for maternal mortality and the babies. This could happen because during their stay in "rumah bulat", mothers and their babies were continually inhaling polluted air from the burned charcoal. Besides, the imperfect combustion from burning the charcoal produced several pollutants such as dust and carbon monoxide (CO), formaldehydes ( $\mathrm{HCHO}$ ), nitrogen oxides (NO), and sulphur oxide (SO), and these substances would harmfully irritate respiratory system[2]. A research conducted by Christiana, Budiyono \& Setyani[3]also mentioned that there was an obvious correlation between the temperature inside "rumah bulat", the concentration of the dust, the tradition of $s e$ ' $i$, the duration of $s e^{\prime} i$, the amount of the burned charcoal, and the cases of ISPA which impacts mothers and their babies. Findings from Anwar\&Rachmalina[5] in their research also stated that mothers and their babies who had undergone sei, most of them suffered from respiratory problems during this last twelve months.

Besides ISPA, a research from Baumali, I Made \& Sumarni[6] firmly mentioned that nutrition insufficiency became a problem for mothers undergoing $s e$ ' $i$ tradition, and efforts to increase the consumption of nutritious food by consuming other sources of food full of nutrition were urgently required. There was also a research from Karwur, Suharmiati, Sakti\& Kristiani[7] which examined participatory actions regarding the tradition in rumah bulat after giving birth from the perspectives of health. The result of this research showed that the willingness of the people in refining the quality of consuming nutrition during the puerperium in rumah bulat was very limited.

The tradition of giving birth to the puerperium in the rumah bulat is obviously different from the one suggested by medical professionals. The treatments toward mothers after giving birth to the puerperium have aims to improve psychological and physical needs for both the mothers and their babies, to do prevention, to have early diagnosis and treat major complications on the mothers, to have vaccine injections if it is required, also to support the implementation of well-feeding methods, and to improve the bond between mothers and babies. It is important for mothers consuming nutritious food during the puerperium and breast feeding since it will have direct impacts on the growth of the nurtured babies. However, as the puerperium ritual in the tradition of rumah bulat, such as se' $i$ that must be undergone by mothers and their babies inside the rumah bulat, also a requirement to consume corns as the only source of food during the tradition seems to neglect important health procedures, so this can be considered to have negative impacts on the mothers and their babies [8].

Findings shown on a research conducted by Mahmoud, Gehan, and Magda[9] stated that $80 \%$ of women did not have sufficient knowledge on the importance of consuming essential nutrition during postpartum. Hence, it is important to inform mothers in improving knowledge about nutrition when having symptoms of blood drains, restoring health, increasing the production of breast milk, and helping to do household activities to be the most important parts in education.

Basically, the knowledge on living a healthy life that can be seen from several aspects such as by concerning the condition of our surroundings, foods, drinks, and other procedures to prevent mothers and their babies from illnesses is knowledge which can be 
absorbed from both formal and informal education. Formal education is structured education which is able to be obtained through passing the elementary level of education, intermediate to university level. While informal education is education or knowledge that can be obtained from living within our family or surroundings. According to the implementation, education that is obtained within our family (informal) plays a very important role since this is the basic education which is acquired by every individual during their first steps in life[10].

In the case on giving treatments to the delivery process and the puerperium of the Boti tribe, Ninu[11] reported that education is the factor that causes the Boti tribe to continue their very traditional life and refuse to use modern medical facilities. The delivery process is normally assisted by witch-doctors or experienced relatives. Traditional tools such as pnio, a piece of bamboo that is used to cut the umbilical cord, unsterilized threads to bind the umbilical cord, a rock on which mothers giving birth, and many more are still used during the delivery process. In addition to that, traditional activities such as massaging the stomach of pregnant women during the delivery process, washing hands without soap, gloves, and mask, without using sterilized equipment, and having corns as the only source of food for the mothers during the puerperium, is the cause of lacking of the influence of formal education within the Boti tribe.

Based on those factors, people of Boti tribe are more obedient to their customs regulations. The belief in using the assistance of witch-doctors also sending mothers and their babies in exile inside rumah bulat has been fossilized and passed down for generations. Every family for generations teaches and passes down this style of living. This is where the role of family education (informal education) has deeply influenced into the core of the culture of Boti tribe[11].

The influence of formal education, although it becomes parts of the socio-cultural lives of Boti tribe, has not yet affected the people of Boti on how to meet the standard of healthy life especially to the women giving birth in the exile. Besides, based on the prevalence measuring mothers with depression during puerperium, the numbers show that mothers who have low incomes tend to live with depression and it also happens to those who live in the areas where the traditions of giving birth is still well-practiced. Many rituals and traditional treatments seem to be the cause of mothers living with depression, trauma, and other psychological problems[12].

Halbreich \& Karkun (in Yuliyanti[13]) mentioned that there were numerous of women with distress after the birth of the first children, and the symptoms could be seen from having difficulty in sleeping, getting tired easily, lacking of concentration, even depression (postpartum blues) for six weeks. The negative impacts of postpartum blues can be seen from the behavior. Losing the desire of daily activities, feeling deeply depressed, losing appetite, losing weight, having insomnia, feeling exhausted, feeling guilty, even planning to commit a suicide.

An interview conducted by Dhanang[14] showed that mothers who had just given birth often crying, feeling depressed, feeling listless, scared, and anxious. It happened because these mothers had to undergo the puerperium in exile inside rumah bulat. These negative reactions and feelings were getting stronger when realizing that their babies had to be inside rumah bulat with its polluted air for quite a long time. Mothers of primigravida would surely feel more depressed knowing that they had no experience before in giving birth and undergoing the puerperium inside rumah bulat. However, this dilemmatic situation had to be endured followed by efforts of the mothers to survive the exile.

Departing from this continuing tradition of giving birth of Boti women (especially the women of Inner Boti) in rumah bulat, the researcher tried to reveal the role of formal and 
informal education in relation to the survivability of Boti women during the exile. Are formal and informal education only parts within the dynamic social life of Boti tribe who strongly maintains its traditional life or these educations also play an important role in how Boti women are able to survive during the exile?

\section{Methodology}

This is a descriptive qualitative research with observation and in-depth interview as the methods of data collection. The participants in this research were divided into two elements which were observation unit and analysis unit. The observation unit consisted of mothers of primigravida, mothers of multigravida, traditional leaders, parents of the mothers being participants, and also the witch-doctors. While those belong to analysis unit were formal education, informal education, socio-cultural traditions, spiritual lives, behavior of the participants during the exile, behavior of the family members outside the exile, emotional reactions of the participants, also psychological experiences and survivability of the participants during the exile. The techniques of the data analysis were done by data reduction, coding, grouping, taking conclusion, and data verification. Data verification was done through triangulation which means by seeking information through secondary participants and observation. Data being collected were analyzed by using descriptive analysis technique.

\section{Results And Discussions}

\section{Results}

Primary Data

Data related to the primary participants which are mothers of primigravida (women who have experienced the exile in rumah bulatfor the first time) and mothers of multigravida (women who have experienced the exile in rumah bulat more than once) are written in the following tables:

Table 1 - Data of primary subjects

\begin{tabular}{|l|c|c|}
\hline \multicolumn{1}{|c|}{ Data / Identity } & Primigravida Subject & Multigravida Subject \\
\hline Age & 28 years old & Elementary \\
\hline Education & Elementary & Farmer \\
\hline Occupation & Farmer & Halaik \\
\hline Belief & Halaik & Inner Boti \\
\hline Origin & Inner Boti & 2 \\
\hline Number of children & 1 & \\
\hline
\end{tabular}

Table 2 - Data of secondary subjects

\begin{tabular}{|l|c|c|c|}
\hline \multicolumn{1}{|c|}{ Data / Identity } & $\begin{array}{c}\text { Traditional Leaders (Mama } \\
\text { Raja Boti) }\end{array}$ & $\begin{array}{c}\text { Traditional Witch-doctors / } \\
\text { midwife }\end{array}$ & $\begin{array}{c}\text { Parents of the subjects } \\
\text { (mother) }\end{array}$ \\
\hline Age & 58 years old & 47 years old & 57 \& 63 years old \\
\hline Education Level & Elementary & Elementary & Elementary \\
\hline Occupation & Farmer & Farmer & Farmer \\
\hline Belief & Halaika & Halaika & Halaika \\
\hline Origin & Inner Boti & Inner Boti & Inner Boti \\
\hline Number of children & - & 5 & $4 \& 6$ \\
\hline
\end{tabular}

\section{Formal and Informal Education for Inner Boti People}

The descriptionof the formal and informal education of the participants/subjects in relation to the traditions from the delivery process to the puerperium inside rumah bulat is provided in the following tables: 
Table 3 - Description of Formal Education

\begin{tabular}{|c|c|c|}
\hline Category & Primigravida Subject & Multigravida Subject \\
\hline Education Accomplishment & $\begin{array}{l}\text { Elementary School. Having } \\
\text { financial limitation became the } \\
\text { reason why did not continue } \\
\text { education to the higher level. }\end{array}$ & $\begin{array}{l}\text { Junior High School. Spent more } \\
\text { time to work helping the family so } \\
\text { did not continue education to the } \\
\text { higher level. }\end{array}$ \\
\hline Education Orientation & $\begin{array}{l}\text { Emphasized more on earning money } \\
\text { than studying at school. }\end{array}$ & $\begin{array}{l}\text { Did not have any orientation on } \\
\text { formal education since having } \\
\text { financial limitations. }\end{array}$ \\
\hline Education Process & $\begin{array}{l}\text { Attended school when permitted by } \\
\text { the parents, and not going to school } \\
\text { when needed to help the parents to } \\
\text { work. }\end{array}$ & $\begin{array}{l}\text { Attended school when there was } \\
\text { time and did not help the parents to } \\
\text { work. }\end{array}$ \\
\hline $\begin{array}{l}\text { Knowledge about Public Health } \\
\text { Center's aids }\end{array}$ & $\begin{array}{l}\text { Knew that the delivery process and } \\
\text { puerperium had to be assisted by } \\
\text { local midwives with standardized } \\
\text { facilities which meet the Public } \\
\text { Health Center's standards. }\end{array}$ & $\begin{array}{l}\text { Got accustomed to traditional } \\
\text { practices during the delivery and } \\
\text { puerperium, although knew that it } \\
\text { was highly recommended in using } \\
\text { health facilities. }\end{array}$ \\
\hline Decision Making Process & $\begin{array}{l}\text { Had no option to have the delivery } \\
\text { process at the Health Center, so } \\
\text { willingly followed the tradition } \\
\text { practices. }\end{array}$ & $\begin{array}{l}\text { Trusted that the traditions would } \\
\text { cause no harm during the delivery } \\
\text { process for both mother and the } \\
\text { baby, so the participant decided to } \\
\text { follow the traditions. }\end{array}$ \\
\hline In-Depth Learning Experiences & $\begin{array}{l}\text { Boti people and their style of life } \\
\text { became guidance from which } \\
\text { everybody could take the values for } \\
\text { life. }\end{array}$ & $\begin{array}{l}\text { Although very traditional and } \\
\text { inappropriate, the participant trusted } \\
\text { the traditions during delivery } \\
\text { process and puerperium }\end{array}$ \\
\hline
\end{tabular}

Table 4 - Description of Informal Education

\begin{tabular}{|c|c|c|}
\hline Category & Primigravida Subject & Multigravida Subject \\
\hline Source of Learning & $\begin{array}{l}\text { Absorbed the knowledge of life from } \\
\text { family and the surrounding people. }\end{array}$ & $\begin{array}{l}\text { Lived with the tradition believed by } \\
\text { Boti people. }\end{array}$ \\
\hline $\begin{array}{l}\text { People's perceptions to the } \\
\text { traditions }\end{array}$ & $\begin{array}{l}\text { Parents played an important role to } \\
\text { remind that maintaining the } \\
\text { traditions was a form of } \\
\text { responsibility in maintaining the Boti } \\
\text { tribe itself. }\end{array}$ & $\begin{array}{l}\text { Preserving the traditions was a } \\
\text { privilege as a part of the community } \\
\text { to show gratefulness to God. }\end{array}$ \\
\hline $\begin{array}{c}\text { Symbolic Meaning of the } \\
\text { Traditions }\end{array}$ & $\begin{array}{l}\text { A 'lopo' is a structure to represent } \\
\text { male Boti tribe who are strong } \\
\text { leader, and the head of a family. } \\
\text { Rumah bulat is a symbol to represent } \\
\text { female Boti tribe who are humble, } \\
\text { and also mothers for their children. }\end{array}$ & $\begin{array}{l}\text { Valued more in self-recognition and } \\
\text { to the meaning of life after } \\
\text { undergoing the delivery process and } \\
\text { puerperium for several times inside } \\
\text { rumah bulat then seeing rumah bulat } \\
\text { itself as a physical structure. }\end{array}$ \\
\hline Concept of a Family & $\begin{array}{l}\text { The Boti tribe itself stands as one } \\
\text { family and home to the participant's } \\
\text { perspective. }\end{array}$ & $\begin{array}{l}\text { The entire Boti people pass down the } \\
\text { values of family unity through their } \\
\text { daily activities. }\end{array}$ \\
\hline Roles of Religions & $\begin{array}{l}\text { The obedience to the religion } \\
\text { (Halaik) and the traditions are } \\
\text { aspects that need to be prioritized } \\
\text { more in the society. }\end{array}$ & $\begin{array}{l}\text { They believe that what Boti people } \\
\text { believe would be for good }\end{array}$ \\
\hline The Tradition of Giving Birth & $\begin{array}{l}\text { Giving birth inside rumah bulat is a } \\
\text { tradition that has been passed down } \\
\text { for generations. }\end{array}$ & $\begin{array}{l}\text { All mothers who bear children have } \\
\text { done their delivery process and } \\
\text { puerperium inside rumah bulat. }\end{array}$ \\
\hline Rumah bulat as a Symbol & $\begin{array}{l}\text { - Rumah bulat itself is a } \\
\text { homestead or symbolizes a } \\
\text { mother to Timor culture that }\end{array}$ & $\begin{array}{l}\text { Rumah bulat becomes the house of } \\
\text { life since inside the building are the } \\
\text { resources, food, ingredients, cooking } \\
\text { process, and also the strengths of the }\end{array}$ \\
\hline
\end{tabular}




\begin{tabular}{|c|c|c|}
\hline & $\begin{array}{l}\text { depicts the unity of the Timor } \\
\text { families. } \\
\text { Rumah bulat is a structure that } \\
\text { has to be build for the first time } \\
\text { before building other houses. It } \\
\text { means that unity and } \\
\text { completeness must be the } \\
\text { foundation of the life of the } \\
\text { family for generations. }\end{array}$ & $\begin{array}{l}\text { afterbirth. Rumah bulat is the center } \\
\text { where a family can fulfill their needs } \\
\text { for life. }\end{array}$ \\
\hline Psychological Experiences & $\begin{array}{l}\text { Admitted that her first experience } \\
\text { during the puerperium inside rumah } \\
\text { bulat was full of anxiety and fear of } \\
\text { the condition of the baby whom } \\
\text { continually exposed to smoke. Even } \\
\text { she planned not to have more } \\
\text { children to avoid living in the rumah } \\
\text { bulat again. }\end{array}$ & $\begin{array}{l}\text { Learning from her first experience } \\
\text { during the puerperium in rumah } \\
\text { bulat so that for the following } \\
\text { process of delivery, she would be } \\
\text { able to overcome the same feelings. }\end{array}$ \\
\hline Emotional Reactions & $\begin{array}{l}\text { Negative emotional reactions } \\
\text { occurred, especially to the family } \\
\text { members (quick tempered, yelling, } \\
\text { being more sensitive, and keep } \\
\text { quiet) }\end{array}$ & $\begin{array}{l}\text { Painful for the first experience, } \\
\text { crying, feeling bored and anxious, } \\
\text { not being able to move freely (small } \\
\text { space to move), but these feelings } \\
\text { would die down after the some more } \\
\text { experiences. }\end{array}$ \\
\hline The Delivery Process & $\begin{array}{l}\text { - Traditional Midwives helped } \\
\text { during the pregnancy with } \\
\text { massaging the belly to the } \\
\text { delivery process. } \\
\text { - The delivery process inside } \\
\text { rumah bulat used traditional } \\
\text { methods and tools. }\end{array}$ & $\begin{array}{l}\text { - Experienced woman helped the } \\
\text { delivery process. } \\
\text { - Ritual sequences of Boti people } \\
\text { need to be followed from the } \\
\text { pregnancy to the puerperium. }\end{array}$ \\
\hline $\begin{array}{l}\text { Tradition intervention during } \\
\text { pregnancy }\end{array}$ & $\begin{array}{l}\text { - Massaging had to be done } \\
\text { starting from the second month } \\
\text { of pregnancy to ensure the } \\
\text { position of the fetus. It aimed to } \\
\text { prevent any risk from happening } \\
\text { since the delivery would only } \\
\text { use traditional tools. } \\
\text { During the massage, there would } \\
\text { be communication between the } \\
\text { mother and the witch-doctor to } \\
\text { strengthen the mother mentally. }\end{array}$ & $\begin{array}{l}\text { - Massaging had to be done } \\
\text { starting from the second month } \\
\text { of preganancy. } \\
\text { - When the preganancy reached } \\
\text { the second month, massaging } \\
\text { could be done as the form of } \\
\text { tradition intervention. } \\
\text { - Both mother, the society, and the } \\
\text { witch-doctor gave their support, } \\
\text { concern, and strengths during the } \\
\text { pregnancy. }\end{array}$ \\
\hline Trusted Subject & $\begin{array}{l}\text { - Witch-doctor or midwife, also } \\
\text { the nuclear family. }\end{array}$ & $\begin{array}{l}\text { - Trusted witch-doctor or mothers } \\
\text { of the close relatives. }\end{array}$ \\
\hline Belief & $\begin{array}{l}\text { - Learn to believe that traditional } \\
\text { rituals used inside rumah bulat } \\
\text { were not harmful. }\end{array}$ & $\begin{array}{l}\text { - Got accustomed to traditional } \\
\text { methods done for generations, } \\
\text { the impact was for the following } \\
\text { puerperium, the participant felt } \\
\text { more confident. }\end{array}$ \\
\hline Roles of Socio-Cultural & $\begin{array}{l}\text { Traditional values learned from the } \\
\text { family need to be practiced every } \\
\text { and fossilized in people's mind. }\end{array}$ & $\begin{array}{l}\text { The Socio-cultural environtment has } \\
\text { immerged to their daily needs since } \\
\text { Boti people accept the local as one } \\
\text { family. }\end{array}$ \\
\hline $\begin{array}{c}\text { Nutrition Consumption for } \\
\text { mothers }\end{array}$ & $\begin{array}{l}\text { Corn was the only source of food } \\
\text { that had been passed down for } \\
\text { generations }\end{array}$ & $\begin{array}{l}\text { During the puerperium of } 40 \text { days, } \\
\text { corn was the only source. }\end{array}$ \\
\hline Physical Environment & $\begin{array}{l}\text { - No ventilation. } \\
\text { - Only } 2 \text { meters for space. } \\
\text { - No windows. } \\
\text { - Fresh water is also limited. }\end{array}$ & $\begin{array}{l}\text { - No ventilation. } \\
\text { - Windows and Door were entirely } \\
\text { closed. } \\
\text { - Diameter of the room was } 2\end{array}$ \\
\hline
\end{tabular}




\begin{tabular}{|l|l|l|}
\hline$\bullet$ & $\begin{array}{l}\text { Floor: dirt } \\
\text { There was no cloth to cover the } \\
\text { mothers while the glass and } \\
\text { plates were not clean }\end{array}$ & $\begin{array}{l}\text { meters. } \\
\text { No ventilation, windows, or even } \\
\text { closed door. } \\
\text { No windows for closed } \\
\text { ceremony. } \\
\text { The diameter of the rumah } \\
\text { bulatbecaused my eyes. } \\
\text { Fresh water limitation. } \\
\text { The floor were made from rocks. }\end{array}$ \\
\hline
\end{tabular}

\section{Discussions}

Either formal or informal education has aims to develop cognitive, affective, and psychomotor abilities of a person to better and useful purposes. Generally, formal education taken by Boti people is similar to that in other places which is through education institutions or schools. The people of Boti have also taken formal education for generations, even though there are some difficulties related to the lack of proper infrastructure, education facilities, numbers of teachers, financial matters, and also other factors. Therefore, remembering these limitations, the quality of formal education from the elementary level to the intermediate level taken by Boti people is difficult to meet the standard of proper education.

Referring to the findings, we are able to know the diverse perspectives and mindset of people in seeing formal and informal education. It was admitted that formal education had been taken by the society, but this formal education could not entirely answer the needs of this very traditional society. To the Boti people, it was the government that necessitated Boti people to take formal education in order to follow the development of the technology, to embrace the modernization, fulfill the needs of the society, and replace the local wisdom. These perspectives seem to becomethe contradiction with the identity and the essence of Inner Boti tribe. To the Boti people, formal education should continue in maintaining the uniqueness of Boti culture.

The people of Boti believed that maintaining the tradition is in accordance to the values of life which is considered as a truth, and these people will preserve this at all risk. Even though the people of Boti still strictly maintain their tradition, they are still opened and willing to send their children to schools or formal institutions. By seeing this, we can conclude that Boti people are actually aware of the importance of formal education in order to broaden their perspectives, acquire knowledge, skills, and to learn good manners. Every Boti family realizes that formal education becomes the way for a brighter future, because as we know that everybody always wants the best for their children.

In line with the formal education being taken, the life of Boti people, especially in the village of Boti, is abundant with family education which is considered as informal education. Every Boti family believe in one philosophy which is to apply the same style of living and social interaction which then becomes the entire Boti's socio-cultural dynamics. As a community that committed in preserving the tradition, their faith in Halaika, and also their traditional practices, this is what these people want their generations to live with.

The informal education with its values that has been inherited for generations has fossilized and well-maintained. The evidence can be seen from the strengths of the children in dealing with the power of nature. Besides, parents become examples and evidence that by doing the tradition such as $s e^{\prime} i$ and tatobi, every mother is able to overcome their daily obstacles, and this strengthens the faith of the children to maintain the same manners. Se' $i$ is believed to strengthen mothers and their babies during the exile in rumah bulat. Moreover, the condition of rumah bulat with no proper ventilation, unhygienic tools and room, and uncovered mothers might cause the exposure of viruses and bacteria more easily. The poor 
quality of formal education and informal education which less concerns about living a healthy life cause mothers undergoing the exile in rumah bulat to live in inappropriate environment. According to Sulfasyah \& Jamaluddin[10], informal education should be the basic knowledge in introducing and emphasizing a healthy life. However, if the formal education fails to impact the society, so does the informal education. Similar to this, Ninu[11] also revealed that the reason why Boti people keep maintaining the traditional life and refuse to use health facilities is because of the education.

In addition, Boti people still believe that corn is the only source of food that is allowed to consume during the exile in rumah bulat. It happens because the people believe that corn is good for easing the breast milk, but people also worry if corn is consumed with other sources of food, it could harm the internal organs of the mothers. Eating corn as the only source of food might cause malnutrition, boredom, and losing appetite that may have direct impact on the immune of the mothers. This is in line with what Baumali[6] had mentioned previously saying that the nutrition consumed by mothers during the puerperium or se' $i$ is not sufficient. Also, Karwur[7] stated that the quality of nutrition in the tradition inside rumah bulat was very limited and needed to improve.

Related to the survivability of women in exile during the puerperium, informal education taught by parents, relatives, and the society plays more important role than that of formal education. Boti women at no time can break the rules during the exile, meaning that they have no other options but to undergo the tradition. In the other hand, it also means that psychological dilemmatic such as fear, anxiety, attention to the condition of the babies, even depression become the strength of the mothers to accomplish the exile. The exile becomes an opportunity for both mothers of primigravida and multigravida to adapt their roles as new mothers, discover self-meaning, and become stronger.

The existence of the surrounding people, as the informal educators, has given an impact from their supports such as attention, psychological, spiritual, and social supports, also resources during the exile. As a result, the role of informal education emphasized continually by the traditional leaders has forced the subjects to maintain the beliefs and tradition. This factor has shaped Boti women to survive during the exile although undergoing psychological dilemmatic such as depression, anxiety, or even trauma.

\section{Conclusion}

Although the people of Boti has experienced formal education, however they receive more influence from informal education especially in integrating themselves with the local traditions which have been well-maintained such as the tradition of living in rumah bulat for women during the puerperium. It happens because rumah bulat is the center of life, center of the unity within the family, also the center of the cultural values that need to be preserved. Because of the inappropriate quality of the formal education, it causes the women of Boti to face difficulty in applying or living the healthy life to answer their physical needs. Informal education taken from their relatives and the society has shown their concerns and supports to shape their ability in surviving the exile. Thus, informal education seems to be more dominant since it shows more important roles during the exile than that of formal education.

Some of suggestions as recommendation for future research are about improve the quality of education that meets the standard of National Requirements especially for elementary level to intermediate level, and also how to provide information regarding the maintenance of physical and environmental health. It is important to provide training about sterilized equipment used by witch-doctors in supporting the delivery process and also have a 
compilation of Boti women psychological model in rumah bulat which is based on local wisdom.

This research would provide much more information if completed with quantitative examination in order to compile the psychological models more accurately. Besides, the numbers of between generations becoming participants were still limited.

\section{Acknowledgment}

This research is fully supported and financed by Hibah Penelitian Tim Pascasarjana by Kemenristek Dikti TA 2018.

\section{References}

[1] P. A. Andung, "Komunikasi ritual natoni masyarakat adat Boti Dalam di Nusa Tenggara Timur," J. Ilmu Komun., vol. 8(1), pp. 36-44, 2010.

[2] Y. W. S. Rachmalina, "Persepsi dan sikap masyarakat desa di Kabupaten TTS tentang melahirkan," J. Kesehat. Reproduksi, vol. 4(1), pp. 16-22, 2013.

[3] o. S. N. R. Christiana, Budiyono, "Hubungan kondisi kesehatan lingkungan Rumah Bulat Suku Dawan dan tradisi se'i dengan kejadian ISPA pada bayi di Puskesmas Kuanfatu Kecamatan Kuanfatu," J. Kesehat. Masy., vol. 6(4), pp. 496-504, 2018.

[4] A. Kinasih, Survei dampak Rumah Bulat dan status gizi terhadap kapasitas vital paru pada ibu postpartum yang menggunakan kompres panas di Kecamatan Mollo Tengah NTT. Binaus wajah Pedesaan Timor di abad XXI. Salatiga: Satya WacanaUniversity Press, 2016.

[5] S. R. A. Anwar, "Kesehatan ibu dan bayi yang melakukan tradisi sei dan gambaran kesehatan lingkungan Rumah Bulat (Ume Kbubu) di Kabupaten Timor Tengah Selatan-NTT," J. Kesehat. Reproduksi, vol. 5(1), pp. 56-64, 2014.

[6] S. A. M. Baumali, A. G. I Made, "Nutrient fulfillment of mothers during puerpurium period in the se'i culture at subdistrict of molo selatan district of Timor Tengah Selatan," Heal. Inf. J., vol. 12(1), pp. 639-648, 2014.

[7] D. T. K. F. F. Karwur, Suharmiati, O. B. Sakti, Proses modifikasi tradisi melahirkan dan bayi di desa Binaus, Kecamatan Mollo Tengah, Kabupaten Timor Tengah Selatan, Nusa Tenggara Timur. Binaus Wajah Pedesaan Timor di abad XXI. Salatiga: Satya WacanaUniversity Press, 2016.

[8] N. Aisyaroh, "Efektivitas kunjungan nifas terhadap pengurangan ketidaknyamanan fisik yang terjadi pada ibu selama masa nifas," Maj. Imliah Univ. Islam Sultan Agung, vol. 50(127), 2012.

[9] F. M. B.S. Mahmoud, G. Gehan, "Assessment of nutritional learning need of the mother during postpartum period," Med. J. Cairo Univ., vol. 82(2), pp. 107-111, 2014.

[10] A. J. Sulfasyah, "Implikasi pendidikan non formal pada remaja Arabiatul Adawiyah," J. Equilib. Pendidik. Sosiol., vol. 4 (2), pp. 1-8, 2016.

[11] J. J. A. S. Ninu, "Gambaran penanganan ibu hamil dan bersalin pada suku Boti dalam Kecamatan Ki'e, Kabupaten Timor Tengah Selatan,” Universitas Katolik Widya Mandala Surabaya, 2016.

[12] L. L. D. S. Khalifa, G. Kari, B. Espen, "Determinants of Postnatal Depression in Sudanese Women at 3 Months Postpartum: A Cross-sectional Study," BMJ Open J., vol. 6(3), pp. 1-9, 2016.

[13] L. Yuliyanti, "Gambaran perawatan ibu nifas di wilayah Kecamatan Miri Sragen," Universitas Muhammadiyah Surakarta, 2014. 
[14] D. Dhanang, "Menempa Generasi Timor dengan Nenoboha.". 